\title{
Potret Keber-Agamaan Masyarakat Sumenep
}

\section{Moh. Haris}

harisubaidillah490@gmail.com

STIT Aqidah Usymuni Sumenep

\begin{abstract}
The chanting of the verses of al-quran is still popping up around the regions in the Sumenep Regency region every day even every time, by carrying out the process of reading and learning the quran. This is proof of the strong and strong portrait of the Sumenep community, even on the other hand shows the enthusiasm to ward off the existence of a regulation on al-qur'an illiteracy made by the Sumenep Regency government, which is actually something that is not important
\end{abstract}

Kata Kunci: Gemar membaca al-qur'an, potret keber-agamaan masyarakat

\section{Pendahuluan}

Al-Qur'an adalah kitab suci yang diturunkan Allah SWT kepada Nabi Muhammad SAW, sebagai salah satu rahmat yang tak ada taranya bagi alam semesta. Di dalamnya terkumpul wahyu ilahi yang menjadi petunjuk, pedoman, dan pelajaran bagi siapa yang mempercayai serta mengamalkannya. Bukan itu saja, tetapi Al-Qur'an juga kitab suci terakhir yang diturunkan Allah SWT, yang isinya mencakup segala pokok-pokok syariat yang terdapat dalam kitab-kitab suci yang diturunkan sebelumnya. Karena itu setiap orang yang mempercayai Al- Qur'an, akan bertambah cinta kepadanya, cinta untuk membacanya, untuk mempelajari dan memahaminya serta untuk mengamalkan dan mengajarkannya sampai "merata rahmat-Nya dirasakan dan dikecap oleh penghuni alam semesta. ${ }^{1}$

Al-Qur'an adalah sumber utama ajaran Islam dan merupakan pedoman hidup bagi setiap muslim. Al-Qur'an bukan sekedar memuat petunjuk tentang manusia dengan Tuhannya, tetapi juga mengatur hubungan manusia dengan sesamanya (hablun mina Allāh wa hablun mina an-nās), bahkan hubungan manusia dengan alam sekitarnya. Al-Qur'an sebagaimana diketahui, diturunkan dalam bahasa Arab, baik lafal maupun $u s l u b$-nya. ${ }^{2}$

\footnotetext{
${ }^{1}$ Al-Qur'an dan Terjemahnya, (Jakarta: Departemen Agama RI, 1992), hlm. 120.

${ }^{2}$ Said Agil Husin Al-Munawar, Al-Qur'an Membangun Tradisi Kesalehan Hakiki, (Jakarta: Ciputat Pers, 2002), Cet.2, hal. 3.
} 
Al-Qur'an merupakan pedoman yang abadi untuk kemaslahatan umat manusia, merupakan benteng pertahanan syari'at Islam yang utama serta landasan sentral bagi tegaknya aqidah, ibadah, mu'amalah dan akhlakul karimah. ${ }^{3}$ Dengan kata lain, alQur'an dapat menjamin terciptanya kemaslahatan hidup serta azas untuk memperoleh kebahagiaan hidup di dunia dan di akhirat karena al-Qur'an adalah petunjuk ke jalan yang benar dalam segala aspek kehidupan.

Rasulullah Saw. Bersabda: "Sesungguhnya Allah Azza Wa Jalla membaca surat Thaha dan Surat Yaa Siin 2000 tahun sebelum menciptakan makhluk. Tatkala malaikat mendengar Al-Qur'an, mereka berkata, "Beruntunglah umat yang diturunkan Al-Qur'an ini kepada mereka, dan beruntunglah rongga tubuh yang mengandung Al-Qur'an ini serta beruntung pula lisan yang membacanya." 4

Realitas keber-agamaan masyarakat Sumenep sangat kental dan kuat. Hal ini, dapat dijadikan titik pijak untuk melihat kegemaran dan kemampuan masyarakat Sumenep dalam membaca al-Qur'an, sehingga merupakan barang mustahil jika masyarakat Sumenep secara notabeni dipandang sebagai masyarakat yang buta huruf dalam membaca al-Qur'an.

Membaca al-Qur'an bagi masyarakat Sumenep telah menjadi kegiatan dan aktifitas seharihari. Di Surau-surau, Mushalla, Masjid, bahkan di Pesantren-pesantren selama ini oleh masyarakat Sumenep masih dijadikan sebagai pusat kegiatan pembelajaran al-Qur'an. Di tempat itulah, anakanak, generasi muda, dan masyarakat belajar dan mengasah diri dengan membaca al-Qur'an agar senantiasa lahir sosok yang memiliki prinsip seperti isi dan kandungan al-Qur'an, bahkan membaca al-Qur'an merupakan sebuah keniscayaan bagi keber-agamaan masyarakat Sumenep. ${ }^{5}$

Munculnya Perda (Peraturan Daerah) tentang buta aksara al-Qur'an yang dibuat oleh pemerintah Kabupaten Sumenep perlu dipertanyakan. Apakah selama ini pemerintah Kabupaten Sumenep memandang masyarakat sebagai masyarakat yang notabeni buta di dalam kemampuan membaca al-Qur'an? ataukah lahirnya Perda tersebut, tidak lebih dari hanya sekedar memenuhi hasrat politik dan proyek pemerintah untuk mendapatkan kepentingan semata? Sepertinya pemerintah membuat Perda itu, tidak didasarkan pada sebuah realitas dan kenyataan di lapangan.

\footnotetext{
${ }^{3}$ Sya'ban Muhammad Ismail, Mengenal Qira-at al-Qur'an, terj. AgilHusin Al-Munawar, dkk, Semarang: Dina Utama, 1993, hlm. 3

${ }^{4}$ Zeid Husein Al-Hamid, Ringkasan Ihya' Ulumuddin, (Jakarta: Pustaka Amani, 2007), hlm.115

${ }^{5}$ Wawancara 18 Januari 2020 dengan K. Asnawi Pengasuh PonPes Al-Kiram Candi Dungkek Sumenep.
} 
Realitas di lapangan sangat bertentangan dengan isi dan kandungan Perda tersebut, karena dilihat dari konteks keber-agamaan dan pendidikan al-Qur'an di Kabupaten Sumenep masih marak dilakukan oleh para kiyai, ustad, dan guru di berbagai level dan tingkatan. Sehingga dengan demikian, kemajuan dan perkembangan masyarakat Sumenep dalam bidang pendidikan al-Qur'an tidak kalah meningkatnya dibanding daerah-daerah lain, seperti Pamekasan, Sampang, dan Bangkalan, bahkan ditingkatan regional sampai nasional pun masih bisa di katakan sebagai daerah yang paling gemar masyarakatnya membaca al-Qur'an. ${ }^{6}$

\section{Eksistensi Gemar Membaca Al-Qur'an}

Membaca Al-Qur'an dalam setiap hari, bahkan setiap waktu merupakan sesuatu yang sangat urgen dan penting untuk diaplikasikan, sebab hidup dengan membaca al-qur'an adalah sebuah fenomena yang sangat erat kaitannya dengan ayat yang pertama kali diturunkan oleh Allah ke alam dunia. Dengan membaca, maka pastinya kita akan mendapatkan keistimewaan yang luar biasa, baik di duni maupun di akhirat kelak.

Kegemaran masyarakat Sumenep dalam membaca dan mengembangkan pendidikan alQur'an telah dipengaruhi oleh substansi agama. Sejak awal Islam telah memberikan dorongan kepada seluruh umat islam agar senantiasa "membaca dan membaca". Sebagaima firman Allah di dalam al-Qur'an yang artinya "bacalah dengan menyebut nama Tuhanmu yang telah menciptakan, yang telah menciptakan manusia dari segumpal darah"7. Dalam konteks inilah, membaca sebenarnya telah menempati posisi paling mendasar dalam kehidupan seorang manusia, karena dengan membaca secara substansial dapat memberikan dorongan yang luar biasa untuk senantiasa ingat dan menyebut Tuhan di dalam dirinya. Sehingga membaca al-Qur'an termasuk sebagian dari esensi keber-agamaan masyarakat Sumenep. Karena tidak dikatakan masyarakat sumenep madura jika tidak bisa membaca al-Qur'an. ${ }^{8}$

Ada beberapa konsekuensi logis yang bisa dirasakan oleh orang-orang yang gemar membaca al-qur'an. Pertama, orang yang gemar membaca Al-Quran pada masa hidupnya, di hari kiamat akan mendapat imbalan syafa'at sebagai balasan dari kebaikan yang ia lakukan. Sangat

\footnotetext{
${ }^{7}$ Departemen Agama RI, al-Qur'an dan Terjemahnya, Bandung: CV Penerbit Diponegoro, 2011, QS: Al-alaq, 1-2

${ }^{8}$ Observasi dan wawancara 22 Maret 2020 K. Nurul Khatim, S.Pd., M.Pd.I Pengasuh PonPes Aqidah Suymuni Sumenep.
} 
beruntunglah orang-orang yang suka membaca al-qur'an, sebagaimana Abi Umamah berkata, "Saya telah mendengar Rasulullah saw bersabda, 'Bacalah oleh kalian Al-Quran. Sesungguhnya, ia akan datang pada hari Kiamat sebagai penolong bagi para pembacanya. Bacalah Az-Zahrawayn, yaitu AlBaqarah dan Ali 'Imrân. Sebab keduanya akan datang pada hari Kiamat, seolah-olah dua awan atau dua telaga rendah atau dua kelompok dari urung berbulu, keduanya berhujjah membela para pembacanya. Bacalah Al-Baqarah, karena sesungguhnya mengambilnya adalah berkah dan meninggalkannya akan membawa penyesalan..." (HR. Muslim).

Hadist tersebut, memuat tentang janji Allah, mengenai pemberian syafaat terhadap para pembaca al-qur'an. Syafaat itu, diibaratkan dua awan yang menaungi seseorang yang sedang bejalan diterik matahari, rasa panas yang menyengat pada kulit tidaklah dapat dirasakan sebagaimana panasnya sinar matahari itu sendiri. Bahkan tidak hanya itu, namun disisi lain Allah akan memberikan suatu kemuliaan pada hari Kiamat bagi mereka yang gemar membaca al-qur'an. Rasulullah saw bersabda, "Dikatakan kepada pembawa Al-Quran, 'Bacalah dan naiklah, bacalah sebagaimana kamu membaca di dunia, maka sesungguhnya (tingginya) kedudukan (yang dicapai) pada hari Akhir sesuai ayat yang kamu baca." (HR At-Tirmidzi, Abu Daud, dan An-Nasa'i).

Kemulyaan yang dapat diraih oleh mereka, sudah barang tentu disesuaikan dengan banyaknya jumlah ayat yang dibaca oleh seseorang, jika ayat yang dibaca sedikit maka ia akan mendapat kedudukan rendah di bandingkan dengan orang-orang yang membaca al-qur'an sebanyak-banyaknya. Adanya ungkapan mengenai kedudukan kemulyaan yang disesuaikan dengan jumlah ayat yang dibaca pada hari Kiamat, seharusnya menjadi motivasi besar bagi kita sekalian sebagai umat islam agar senantiasa memperbanyak membaca al-qur'an, dengan harapan kita dapat memperoleh kedudukan yang tinggi di sisi Allah. Jika disadari betapa hebatnya orang-orang yang selama ini masih diberi kesempatan untuk melantunkan ayat-ayat suci al-qur'an, sehingga dari saking hebatnya derajatnya disejajarkan oleh Allah dengan para malaikat. Didalam hadist Rasulullah saw, yang riwayatkan oleh Imam Bukhari disebutkan bahwa ”Orang yang membaca AlQuran dengan mahir, akan bersama-sama malaikat yang mulia lagi taat, dan orang yang membaca Al-Quran dengan terbata-bata lagi merasa berat, maka ia mendapat dua pahala." (HR Bukhari). ${ }^{9}$

Kedua, Allah SWT akan memberikan suatu keistimewaan terhadap mereka para pembaca al-qur'an di antara sekian banyak makhluk yang telah diciptakan Allah di muka bumi ini. Sehingga Rasulullah saw menegaskan di dalam sabdanya mengenai hal tersebut, "Tidak ada rasa iri, kecuali

\footnotetext{
${ }^{9}$ Imam Zabini, Ringkasan Shahih Al-Bukhari (Bandung: Mizan, 2003) hlm. 79
} 
kapada dua perkara, (yaitu) seseorang yang diberi Allah Al-Quran, maka ia mengamalkannya siang dan malam. dan, seseorang yang diberi harta, maka ia menginfakkannya siang dan malam.” (HR Bukhari Muslim). Mengamalkan al-qur'an tidak hanya sekedar membaca, namun yang terpenting dari kandungan hadits itu, merupakan anjuran untuk membuktikan dan merefleksikan isi dan kandungannya dalam realitas kehidupan kita sehari-hari. Artinya, segala tetek bengik kehidupan yang kita jalani hendaknya di hiasi dengan aturan main yang telah ditetapkan olah Allah di dalam al-qur'an. Sangatlah pas dengan apa telah diungkapkan oleh Abdullah, bahwa al-qur'an diturunkan ke duania merupakan pedoman etika, moral dan akhlak manusia dalam menjalani hidupnya di dunia. Jika hal ini, mampu untuk kita lakukan maka pastinya Allah akan memberikan sebuah keistimewaan. Sebab, apa yang kita lakukan, baik yang sifatnya hubungan dangan Allah, manusia, dan lingkungan al-qur'anlah yang menjadi pijakannya.

Orang-orang yang selama ini hidupnya selalu digantungkan dan disibukkan dengan membaca dan mengamalkan al-qur'an termsuk orang-orang yang sangat beruntung, karena ia adalah orang yang selalu berupa semaksimal mungkin untuk kembali dan patuh serta bertekut lutut dibawah naungan dan aturan al-qur'an, sebab al-qur'an diturunkan ke dunia sebagai pembenar. Jadi siapapun dan bagaimanapun keadaannya, jika ia mau kembali kepada al-qur'an berarti telah mendapatkan anugrah yang luar biasa dari Allah, dengan diberikan keistimewaan diantara mahluk lainnya.

Ketiga, anugrah terbaik akan diberikan oleh Allah SWT semasa hidupnya bagi orangorang yang gemar membaca al-qu'an. Di dalam hadist Rasulullah saw disebutkan, "Barang siapa sibuk dengan Al-Quran (melebihi daripada sibuk) dengan zikir dan memohon (berdoa) kepada-Ku, niscaya Aku akan berikan kepadanya karunia yang lebih utama yang Aku berikan kepada orangorang yang memohon (berdoa). Dan, keutamaan kalam Allah di atas semua ungkapan, laksana keagungan Allah di atas semua makhluk-Nya." (HR Tirmidzi). Dalam hadist ini, dapat dipetik sebuah konglusi bahwa orang-orang yang dirinya selalu disibukkan dengan al-qur'an, baik membaca maupun mengamalkannya akan diberi karunia yang lebih utama dibanding dengan orang yang memohon doa kepada Allah.

Keempat, Allah SWT akan menganugerahkan ketenangan batin kepadanya. Rasulullah saw bersabda, "Kepada kaum yang suka berjamaah di masjid-masjid, mengajarkan Al-Quran secara bergiliran dan mengajarkannya terhadap sesama, akan turunlah kepada mereka ketenangan dan ketenteraman, akan terlimpah kepadanya rahmat dan mereka pun akan dijaga oleh malaikat, juga 
Allah akan senantiasa mengingat mereka.". Dalam perspektif Faizur Rosyad, orang yang membaca al-qur'an akan merasa damai karena didalamnya terkandung nasehat-nasehat dan anjuran yang secara substansial bertumpu pada sebuah kebaikan.. Selain itu, dia juga akan memperoleh kebahagian di dunia dan akhirat kelak. ${ }^{10}$

Seseorang yang rajin membaca al-qur'an dalam setiap hari, merupakan potret dari keberagamaan masyarakat yang kokoh dan kuat. Al-qur'an jika selalu di baca, walaupun tidak bisa difahami maknanya, maka pastinya akan membawa dampak yang luar biasa baik pada jiwa dan raga kita. Rasulullah saw. Bersabda, "Sesungguhnya hati bisa berkarat sebagaimana besi, maka ditanyakan kepada beliau "Ya Rasulullah", apa penghilangnya? Rasulullah menjawab: "Membaca Al-Qur'an dan mengingat mati”. (HR.Baihaqi). Dalam hadist lain, Rasulullah saw. bersabda terkait dengan keutamaan membaca al-qur'an, yang artinya, ““'Sebaik-baik kalian adalah orang yang belajar Al-Qur'an dan mengajarkannya." (HR. Al-Bukhari). ${ }^{11}$

Dalam kandungan hadist tersebut, ada pesan luar biasa yang harus kita fahami sebagai upaya untuk memdorong diri kita agar senantiasa memiliki keinginan besar untuk mengembangkan dan meningkatkan pola hidup dengan membaca al-qur'an. Isi dan kandungan al-qur'an memuat tentang seluruh kebaikan dan keutamaan, sehingga Allah SWT. menjanjikan sesuatu yang luar biasa kepada orang-orang yang tekun dan rajin membaca al-qur'an, ia akan dibersihkan hatinya dari berbagai penyakit dan kotoran, sperti penyakit iri, dengki, hasut, dzalim, sombong, dan lain sebagainya. Dalam konteks ini, telah nampak jelas bahwa orang-orang yang suka membaca alqur'an akan diberi kehebatan dengan kebaikan dan keutamaan, bahkan akan senantiasa selalu terhindar dari segala penyakit yang akan menjerumuskan dirinya pada lembah kehinaan.

Dari kempat point di atas, menunjukkan kehebatan dan keistimewaan orang-orang yang gemar membaca al-qur'an, jika al-qur'an dibaca sebagai upaya untuk memperkokoh dan memperkuat diri kita dalam berpegang teguh pada aturan Allah yang telah ditetapkan di dalam alqur'an. Namun harus disadari bahwa membaca al-qur'an, termasuk upaya maksimal dilakukan oleh seseorang dalam berpegang teguh pada aturan Allah, yang kemudian pada gilirannya dapat difahami sebagai potret keber-agamaan masyarakat. Di Kabupaten Sumenep lantunan ayat-ayat suci al-qur'an dan proses pembelajaran al-qur'an masih terlihat jelas dan nampak dihadapan mata kita,

\footnotetext{
${ }^{10}$ Ahmad Faizur Rosyad, Mengenal Alam Suci;Menapak Jejak Al-Ghazali Tasawuf, Filsafat dan Tradisi, ( Yokyakarta : KUTUB, 2004),hlm.125

${ }^{11}$ Imam Zabini, Ringkasan Shahih Al-Bukhari (Bandung: Mizan, 2003) hlm. 48
} 
sehingga lahirnya perda tentang buta huruf al-qur'an menuai banyak polemik ditingkatan masyarakat, sebab adanya perda tersebut tidak sesuai dengan fakta dan realita di lapangan.

\section{Membaca dan mengajar al-Qur'an; tradisi keber-agamaan masyarakat}

Mengaji Al-Qur'an sejak dulu telah menjadi budaya masyarakat Indonesia. Namun, akhirakhir ini mengaji Alquran sudah mulai ditinggalkan. Umat Islam lebih asik mengikuti sinetron dan film seraya duduk berlama-lama di depan televisi dari pada membuka mushaf Al-Qur'an.

Saat ini, banyak dijumpai anak yang masuk ke jenjang sekolah menengah pertama masih belum lancar dalam membaca Al-Qur'an. Hal ini menjadi suatu keprihatinan bahwa seusia mereka yang tengah menginjak masa remaja, di mana membaca Al-Qur'an yang merupakan kitab suci umat Islam ini dirasa kurang begitu diperhatikan sejak mereka kecil. Pendidikan Al-Qur'an hendaknya diperkenalkan kepada anak sedini mungkin terutama dalam hal membaca, karena belajar Al-Qur'an merupakan suatu proses yang berawal dari mengeja huruf-huruf hijaiyah sampai dengan cara membaca Al-Qur'an secara menyeluruh dan itu semua membutuhkan waktu yang tidak sebentar serta ketekunan yang tinggi.

Untuk dapat membaca Al-Qur'an dengan baik dan benar, Kementerian Agama (Kemenag) RI ingin mengembalikan tradisi mengaji setiap selesai shalat Maghrib dapat kembali dihidupkan di seluruh pelosok negeri. Masyarakat diajak untuk kembali membuka Al-Qur'an. kendati mereka sudah khatam Al-Qur'an sebelumnya. Dengan mengaji selepas shalat Maghrib, pengaruh pengaruh negatif dari televisi dan media elektronik lainnya bisa diminimalisasi. Kementerian Agama (Kemenag) RI telah mencanangkan Gerakan Masyarakat Maghrib Mengaji atau yang lebih dikenal dengan GEMMAR Mengaji. GEMMAR Mengaji adalah sebuah program untuk membudayakan membaca Al-Qur'an setelah shalat Maghrib di kalangan masyarakat. ${ }^{12}$

Membaca dan mempelajari al-qur'an di Kabupaten Sumenep telah menjadi tradisi mulia secara turun menurun di kalangan masyarakat sumenep. Hal ini dapat kita lihat di Surau-surau, Mushallah, Masjid, menjadi tempat pertama dalam proses membaca dan pembalajaran al-qur'an, baru kemudian dilanjutkan ke Pesantren untuk dikembangkan dan tingkatkan kemampuan mereka. ${ }^{13}$ Al-qur'an diajarkan dalam rangka untuk memberikan dorongan dan penyadaran pada generasi muda

\footnotetext{
12 http://www.republika.co.id/berita/koran/dialog-jumat/14/06/06/n6qgo72-prof-drnasaruddin-umar-mengembalikanbudaya-mengaji-umat-islam, diakses pada tanggal 23 Juli 2015.

${ }^{13}$ Observasi dan wawancara 15 Februari 2020 K. Nurul Khatim, S.Pd., M.Pd.I Pengasuh PonPes Aqidah Suymuni Sumenep.
} 
betapa pentingnya membaca dan mempelajari al-qur'an secara terus-menerus sampai akhir zaman. Oleh karena itulah, Faizur Rosyad mengungkapkan bahwa bagi orang-orang islam sangat dianjurkan untuk membaca al-qur'an dengan berulang-ulang walaupun tidak memahami maknanya. Namun bagi yang mampu memahami maknanya akan lebih utama kedudukannya. ${ }^{14}$

Kata berulang-berulang berarti merupakan sebuah dorongan untuk mentradisikan membaca al-qur'an. Di kalangan masyarakat Sumenep tradisi membaca dan mengajarkan al-qur'an telah menjadi fenomina yang sangat kental dengan aktifitas dan kondisi masyarakat dalam setiap hari bahkan setiap waktu. Di tempat-tempat ibadah dan di rumah-ramah lantunan ayat-ayat suci alqur'an masih marak di lakukan oleh masyarakat, yang secara otomatis merupakan tradisi mulia dari keber-agamaan masyarakat Sumenep. Disisi lain adanya aktifitas yang demikian, yakni membaca al-qur'an sebagai tradisi keber-agamaan, sebenarnya merupakan perwujudan dari tanggung jawab seorang manusia untuk membentuk dan melahirkan masyarakat yang memiliki mental seperti apa yang terkandung di dalam al-qur'an, yang kemudian pada gilirannya dapat menyelesaikan persoalan masyarakat dari ketidak tahuan—buta—dalam membaca al-qur'an.

Hal lain, yang bisa dijadikan pijakan untuk melihat potret keber-agamaan masyarakat Sumenep masih banyaknya kelompok-kelompok yang melakukan aktifitas dengan membaca alqur'an, seperti adanya tadarrus bersama, undangan hatmil qur'an, dan kegiatan-kegitan lain yang diisi dengan pengajian, pengajaran dan membaca al-qur'an. Kebiasaan-kebiasaan semacam ini, oleh Tasmara dikatakan sangat besar pengaruhnya pada pola pikir dan tindakan seorang manusia. Sayangnya, lebih banyak orang yang tidak menyadari bahwa setiap kebiasaan yang dilakukannya menentukan corak dan warna hidupnya. Untuk itu, agama islam mencoba untuk memupuk semangat dan mentradisikan membaca al-qur'an bagi umat islam pada umumnya, khususnya di Kabupaten Sumenep yang sampai hari ini masih menjadi tradisi Islam yang luar biasa. Lebih lanjut, Tasmara mengatakan bahwa tradisi tersebut adalah membiasakan diri dengan membaca, menelaah, membicarakan, dan mengaplikasikan makna kandungan al-qur'an dalam kehidupan sehari-hari. Karena, al-qur'an merupakan sumber inspirasi yang tidak kring untuk dibaca, dikaji, ditelaah sampai akhir zaman. ${ }^{15}$

\footnotetext{
${ }^{14}$ Ahmad Faizur Rosyad, Mengenal Alam Suci;Menapak Jejak Al-Ghazali Tasawuf, Filsafat dan Tradisi, ( Yokyakarta : KUTUB.),hlm. 145

${ }^{15}$ Toto Tasmara, 2000. Menuju Muslim Kaffah; Menggali Potensi Diri, (Jakarta : Gema Insani), hlm. 57
} 
Lahirnya perda tentang buta huruf al-qur'an di Kabupaten Sumenep telah mengkikis nilai dan substansi tradisi keber-agamaan. Islam dengan seperangkat aturan dan undang-undangnya semuanya telah tercantum di dalam al-qur'an, dan sampai hari ini tetap menjadi pijakan mendasar di kalangan masyarakat sumenep, sehingga lahirnya perda tersebut menjadi tidak wajar. Oleh sebab itu, dalam perspektif Abuddin Nata, bahwa untuk memahami islam secara komfrehensip dengan berpedoman kepada semangat dan isi ajaran al-qur'an yang diketahui mengandung banyak aspek. Berbagai aspek di dalam al-qur'an jika dipelajari secara keseluruhannya akan menghasilkan pemahaman Islam yang menyeluruh.

Sudah semakin jelas, bahwa lahirnya tradisi keber-agamaan masyarakat Sumenep tidak bisa lepas dari isi dan kandungan al-qur'an. Al-Qur'an mengandung semangat yang luar biasa mengenai tradisi membaca al-qur'an, hal ini dari dulu sampai saat ini telah mendapat respon positif di kalangan masyarakat Sumenep, dengan melaksanakan proses pengajaran dan membaca al-qur'an dalam setiap hari bahkan setiap waktu. Oleh karena itu, karena membaca al-qur'an merupakan tradisi keber-agamaan masyarakat Sumenep, hendaknya harus ditradisikan sepanjang sejarah kehidupan seorang manusia, agar senantiasa terbentuk dan lahir manusia yang berjiwa qur'ani.

\section{Penutup}

Dari penjabaran di atas, dapat ditari sebuah konglusi bahwa potret keber-agamaan masyarakat Sumenep dapat dilihat dari semangat dan kegemaran masyarakat dalam membaca alqur'an. Semangat dan kegemaran ini, kita tidak hanya ditemukan di tempat-tempat yang menjadi tempat pembelajaran membaca al-qur'an, seperti di Masjid, Mushallah, dan Surau-surau, namun di rumah-rumah masyarakat sekalipun masih terdengar lantunan ayat-ayat suci al-qur'an. Ini merupakan salah satu bukti, bahwa masyarakat Sumenep secara notabeni tidak buta di dalam mebaca al-qur'an, sehingga lahirnya perda tentang buta huruf al-qur'an menjadi sesuatu yang tidak penting dan sia-sialah keberadaannya. 
Tafhim Al-'Ilmi : Jurnal Pendidikan dan Pemikiran Islam Terakreditasi Nasional SK No : 148/M/KPT/2020
ISSN: 2252-4924, e-ISSN: 2579-7182

Volume 12, No. 1 September 2020

\section{Daftar Pustaka}

Abdullah, M.Amin, Dr. 2002. Studi Agama; Normatifitas atau Historisitas?, Yokyakarta: Pustaka Pelajar.

Departemen Agama RI. 1992. Al-Quran dan Terjemahnya. Jakarta: Gema Risalah Press.

Halim, Muhammad Abdul. 2002. Memahami Al-Quran. Bandung: Narja'.

http://www.republika.co.id/berita/koran/dialog-jumat/14/06/06/n6qgo72-prof-drnasaruddin-umarmengembalikan-budaya-mengaji-umat-islam

Nata, Abuddin, Dr, MA. 2000. Metodologi Studi Islam, Jakarta : RajaGrafindo Persada.

Rosyad, Ahmad Faizur. 2004. Mengenal Alam Suci;Menapak Jejak Al-Ghazali Tasawuf, Filsafat dan Tradisi, Yokyakarta : KUTUB.

Ismail, Sya'ban Muhammad, 1993. Mengenal Qira-at al-Qur'an, terj. AgilHusin Al-Munawar, dkk, Semarang: Dina Utama, hlm.

Tasmara, Toto, Drs. 2000. Menuju Muslim Kaffah; Menggali Potensi Diri, Jakarta : Gema Insani.

Zabini, Imam. 2003. Ringkasan Shahih Al-Bukhari. Bandung: Mizan.

Al-Hamid, Zeid Husein, 2007 Ringkasan Ihya’ Ulumuddin, Jakarta: Pustaka Amani

Al-Munawar, Said Agil Husin, 2002 Al-Qur'an Membangun Tradisi Kesalehan Hakiki, Jakarta: Ciputat Pers.

Ismail, Sya'ban Muhammad, 1993 Mengenal Qira-at al-Qur'an, terj. AgilHusin Al-Munawar, dkk, Semarang: Dina Utama. 